Elżbieta Młyńska

Biatystok

\title{
Painting Françoise Bürtz at the confluence of modernity and sacrum
}

French contemporary painter Françoise Bürtz has studied the art of painting in Paris since 1962. In a meeting with the French avant-garde, Henri Matisse, Marc Chagall, Pablo Picasso and at the same time philosophers pioneering the path of modern art such as Jean Paul Sartre, André Malraux could well get to know its expressions and assumptions. The art of which she encountered was temporary, and creation devoid of contemplation became a production cycle, resulting in the soulless creatures of rapid invention. Françoise Bürtz, discouraged by art deprived of its depth of art, began looking for something else. She abandoned the environment that could provide her an artistic career. After experiencing a personal conversion to the path of faith, she took the initiative to create an art that would lead her recipients to personal contact with God. In working out the original assumptions of the new style of creation, helped her contact with the stigma of Marthe Robin, the exegete maker Mess'AJE Jacques Bernard, as well as the stay in the Holy Land, the theological studies in Friborg, and a trip to Russia. Based on these experiences as well as the contemplation of the biblical texts and the Fathers of the Church, she created a new civilization of the religious image in which it combines the achievements of contemporary art with the attempt to express the invisible. Her numerous works are a kind of great theological synthesis, which is an important aid in the biblical education of adults on several continents. This art combines modern expressions with the depths of the mystery of faith effectively leading the modern man to meet the sacred..

Key words: French avant garde, eastern iconography, theological synthesis, model in art, sacrum. 
Françoise Bürtz is a French painter, whose work is the result of a consistent and intentional search for a connection between contemporary art and the sacred. Her artistic personality was shaped in the sixties of the twentieth century in the context of the socio-cultural conditions of that time, as well as the philosophical currents on which the postwar France based the vision of a happy life. While it was not easy to define the canons of modern French art, the understanding of the sacred was also evolving. The art of modernism, continuing the French avant-garde movement in the nineteenth century, was celebrating the triumphs of the sixties. No wonder that the painter living in the center of events and ideas was marked by the spirit of that time. Through confrontation with them, she learned to perceive in modern art what she considered her value and why she decided to remain faithful in her work. Impressive in the life of the painter was a persistent search for an answer to the question of the sacred, which she tried to familiarize with the recipients of her works. The confrontation of the avant-garde art of the West with the theological picture of the East gave her work the features of original painting, which attracted the interest and appreciation of both artists ${ }^{1}$.

Creating her own style of painting images - known as theological icons - the childhood together with the painter's mother, the formation of the Parisian vanguard, the encounter with the significant personalities of contemporary mystics and theologians, and the encounter with the art of the Christian East in Russia were of great importance. As a result of these meetings and formation, she created a new generation of religious and sacred images.

\section{The origin of painting}

Françoise Bürtz was born in 1942 in the small town of Isenheim in Alsaca, which was of no consequence to her artistic development. Also, Françoise's parents were in close contact with art creating a climate that fostered the development of the talents of their youngest child. Under these conditions, Françoise made her first attempt at the age of three ${ }^{2}$. A mother, a well-known painter, as well as a father, a textile engineer ${ }^{3}$, took their daughter to exhibitions for significant

Cf. F. Bürtz, Evangile de Noël, Lille 1991, 3-9.

2 E. Meaney, Representation and synthesis in Françoise Bürtz's Religious Art, Spring 1997, p. 12. Arch. Mess'AJE, Lille. 
museums ${ }^{4}$. Their traveling together became a good opportunity to get to know the works of art recognized for their time. At the age of thirteen, Françoise traveled with her father to Hungary. The stay there gave her the opportunity to meet and talk in an orthodox monk, from which she remembered what function light has in the Eastern iconography. To this event will be referred to as the author of their own paintings painted in the icon convention ${ }^{5}$. From the early biography of the artist we learn that mother surrounded her daughter with painting geniuses ${ }^{6}$. It is thanks to her, a person with a strong temperament and great artistic ambitions, Françoise in her early youth met with representatives of the French avant-garde. Mrs Bürtz invited such artists as Henri Matisse, Marc Chagall and Pablo Picasso to the nearby town of Colmar. The painter came as a child, and in conversation with her mother she made non-trivial matters. She once asked her: Why do I exist?, and she answered her motherly: Because I love you. This reflection continued to ask: Why is there a world? and she got a similar answer. She realized then that the world exists only because it is loved ${ }^{7}$. Contact with the art as well as conversations with her mother during her youth stimulated the development of a future painter. To this day, she mentions them when she discusses philosophical considerations or describes her workshop.

Returning to the place of birth of a future painter, it must be noted that it first of all aroused in her the sensitivity to beauty. The multiwinged altar of German master Matthias Grünewald, who had been living in Imenheim, had revived her imagination from her childhood. The monumental, 16th-century work of passion, embedded in the convention of Gothic art and enriched with elements of Italian art, amazed with the realism of the suffering of crucified Christ ${ }^{8}$. According to master Grünewald, the gothic art did not consist in seeking the hidden rules of beauty, but it had the function of preaching. Therefore, in the painted altar - showing the brutality of suffering - the painter applied two significant for his style of treatment. First of all, the size of the characters depends on the roles they play in the scene they represent. Secondly, he devoted the idea of beauty pleasant for an

4 J-M. Merlin, Françoise Bürtz: l'art comme une vocation, in: Troisième seuil. Jésus. Guide d'animation, ed. III, Lille 2013 annexe 1.2.

5 J-M. Merlin, Françoise Bürtz: l'art comme une vocation, in: Troisième seuil. Jésus. Guide d'animation, ed. III, Lille 2013 annexe 1.2.

F. Bürtz: L’art moderne et la foi, Mess'AJE 2001, 46, p. 5.

F. Bürtz nous entretient de la peinture, Mess'AJE 1982,10, p. 7. 
eye, in favor of exposing the spiritual message of the work ${ }^{9}$. The altar in Isenheim was enough to inspire Françoise that before she went to study art in Paris, she first went to the monastery to write this work in her heart forever. She was under the strong impression of the genius of silence, modernity and theological synthesis. Disturbed by the beauty of Gothic-Renaissance art, she begged the author to become her ,father" in the work of artistic creativity. Matthias Grünewald, for the beginner artist, has become an unmatched model, and as if part of her heart, someone who will never leave her. To emphasize the quality of this bond the creator of the altar in Isenheim called it ,an invisible godfather" $"$.

Although Françoise wanted to study in Paris, her parents' financial troubles prevented her from taking the plunge. The mother sent her daughter to a nursing school in Lille. Since the profession of nurse did not suit her, so she spent her time in school to develop her interests in music, singing, poetry and art. After a year she left school and went to Paris ${ }^{11}$. In order to make a living, she started working in a music store. There, her interests were noticed and she was offered a job in the atelier where she learned to perform small useful instruments. Moreover, together with Cousteau she also experimented with visual art, trying to create a basis for it based on marine forms ${ }^{12}$. He went to the Paris Academy of Fine Arts in 1962.

\section{Creativity in the French avant-garde}

At the same time, the trend of modern art, which since the painter's childhood became fine, began in the nineteenth century and has undergone in its development various stages. In essence, what we call the French avant-garde is a set of trends in art, rejecting the current styles, creating their own world, not imitating reality, seeking a distinct way of expression ${ }^{13}$. The basic principle of avant-garde art was undeniably a break with academicism ${ }^{14}$, whose most important assumption was

$9 \quad$ E.H. Gombrich, O sztuce, Wyd. II. Poznań 2009, 351-353.

$10 \quad$ F. Bürtz, Evangile de Noël ... p. 3.

$11 \quad$ E. Meaney, Representation ... 10-11.

12 F. Bürtz, ibidem p. 5.

$13 \quad$ Cf. Słownik wyrazów obcych, Warszawa 1996, p. 96.

14 „Academics-a current in art based on the rules of antique aesthetics and eclectic imitation of artists and works recognized as excellent, expressing themselves in the limitation of the freedom of independent creative exploration both in the 
to copy the model that remained outside the artist ${ }^{15}$. Françoise Bürtz fully identified with this paradigm.

The French avant-garde dates back to 1874 when the works of the Impressionists were exhibited in Paris. Successively introduced paintings - created at various stages of the development of new art rejected the other rules of academicism, and therefore composition, lightening, perspective, color combination ${ }^{16}$ and presented new paintings. The list of creators of new art and proposals grew over time, and subsequent events stimulated their development. At the time when Françoise Bürtz was educated in Paris, the avant-garde aspirations of the artists in 1968 supported the moral revolution initiated by French students. Young people questioned the norms, including aesthetic standards, in many areas ${ }^{17}$. So it is no wonder that modern French art, or at least that of the artists of different nationalities in Paris, has developed dynamically.

Françoise was particularly interested in the work of Marc Chagall, who praised symbolism, surrealism, expressionism, and painting by Pablo Picasso, co-author of Cubism. Henri Matisse's style was close for her at the same time. Although Henri Matisse died a few years before her studies, reunion with him during her childhood was still alive, and his art in the field of foxism triggered new creative passions. The philosophers who paved the way for modern art, including Jean-Paul Sartre and André Malraux, were among the people in the creative circle for developing her artistic personality. In Paris, she also met Cocteau - an outstanding poet, screenwriter, filmmaker, painter.

The painter, in order to show the direction of the changes taking place in the area of interest, most often referred to the avant-garde fathers: Vincent van Gogh and Paul Cézanne ${ }^{18}$. When analyzing their work, she noticed that the artists, breaking with the principles of academics, and above all with the copying of the model, put their torn interior in their place. This important observation referred to the

selection of subjects as in the application of certain formal means." See. In: M. Poprzęcka, Academizm, Warszawa 1989, 11-19.

15 „Model - otherwise prototype: every pattern (building, furniture, sculpture) imitated and reproduced in similar shape.” In: Stownik terminów plastycznych, K. Zwolińska, Z. Malicki, 5th ed. 1974, p. 185.

16 Por. F. Bürtz, Faire voir l'invisible, Mess'AJE Numéro Hors-Série 1996, p. 23.

$17 \quad$ F. Bürtz, Evangile de Noël, Ibidem.

18 Cf. M. Levey, Od Giotta do Cézanne’a. Zarys historii malarstwa, transl. M. Bańkowska. S. Bańkowski, Warszawa 1972, 306-312. Od Maneta do Pollocka. Stownik malarstwa nowoczesnego. Pracazbiorowa, transl.H. Devechy, Warszawa 1995, 58-65, 136-142. 
Theology of beauty

essential characteristic of modern art, which was justified by their own painters' biographies and ideological transformations which they passed. Their painting, according to Françoise, often revealed the personal drama of the creators and became the scream of a torn soul $^{19}$. These artists, despite their various personal relationships with Christianity, did not take into account in their work references to the realm of the sacred, understood as the realm of human contact with God. For example, Van Gogh, despite his Christian origins, rejected God in his life, and in his works such as „,Still Life with Bible” or ,The sale of Crosses" were announcing the end of the Church. As a declared socialist in his work he glorified human work, the beauty he saw in nature and regarded it as eternal. Nothing, however, indicated that he would discover the Invisible as the creator of the Good, the Truth, and the Beauty. Cézanne, who was only thirty years old, had dark, violent, theatrical paintings in which he wrote his own sexual obsessions and terrifying dreams. He often painted scenes of death, orgies, circus compositions brutally mixing dense blue and white paint. He was afraid of fear, shyness, awkwardness, embarrassment. Although he had systematically performed religious practices in the Catholic Church, his art had no reference to the sacred sphere.

Pablo Picasso ${ }^{20}$ from Spain, met by Françoise, joined the French avant-garde in 1900 . He also radically detached himself from the traditional concept of art. He recognized that ,the academic gospel of beauty is a deception." Regardless of his early artistic endeavors in the subject of misery, loneliness and sadness, he explored the tragedy of the characters by extending or slicing their characters, and later became interested in African art. From then on, his work was marked by a powerful emotional charge and characterized by deformation of the model. From the penetrating observation of ordinary objects, he extracted their interior, shape, structure, surfaces, center and bottom. In this way he made a significant contribution to the development of Cubism. A characteristic feature of his work was that he focused on such transposition of forms to suggest that the viewer was different from the present-day world. The same Picasso made fake things by implanting pieces of newspapers and a box of matches into his paintings. He drew and painted on everything that fell into his hand - paper napkins, wrapping paper, raw wood, dicta, fibreboard. The canvas was primed neatly, carelessly selected paint and tools. Picasso succumbed to the temptation of surrealism, which was deliberately destructive

\footnotetext{
$19 \quad$ F. Bürtz: L'art moderne ... p. 4.

$20 \quad$ Cf. Od Maneta do Pollocka ... 270-276.
} 
and nihilistic. He also used poor painting tools. Many of his works were explorations of dreams and internal impulses. His work from the war period was horrified by the horror and distortion of human form. Even after the war, all his works were mysteriously violent, his own tear and anxiety. In the fifties of the twentieth century, he undertook artistic challenges in the realm of naturalism, expressionism, classicism, romanticism and abstraction. Throughout his work dominated the inconvenient anxiety, the drama of man's struggle with nature, rebellion against human fate ${ }^{21}$. Pablo Picasso was a Communist. He claimed that art has no past or future. Everything he did was in the present. He once declared that he would do anything to occupy the place of the model and hence there would be no more art ${ }^{22}$.

Henri Matisse ${ }^{23}$, a Frenchman, was a man of constant anxiety. He countered and sublimated his inhibitions. In the first phase, his art, called conservative, was fed on the tradition of the highest aspirations. At the end of the nineteenth century, the artist met with the Impressionist movement, which enabled him to develop the world of his artistic accomplishments. After these experiences and creative pursuits, he gained the fame of the king. He was famous as a brilliant colorist, who replaced the chiaroscuro with contrasting colors. His paintings filled with stains of lively, luminous, usually strongly contrasting colors, which often surrounded the delicate contour in the interest of the readability of the image. But he did not stay on the fowzy. He has been experimenting with painting for many years, performing sculptures, and has also gone to abstraction without compromising. Françoise remembers a childish encounter where she was interested in his painting style. Having an apple in front of him, he persuaded Françoise not to paint the apples, but its redness. It was a clear signal from the artist that the painted object under his brush became an abstraction. In this way, Matisse, according to the painter's reflection, was leading a tragic emptiness in the world ${ }^{24}$. Although he was respectful of the proposal to paint the chapel of the Dominican Sisters in Vence, he still remained faithful to his assumptions. While presenting the saints, he painted blank ovals of faces surrounded by

$21 \quad$ Por.OdManeta do Pollocka...270-276; W. Beckett, Historia malarstwa. Wędrówki po historii sztuki Zachodu, transl. H. Andrzejewska, I. Zych, Warszawa 1996, 346-349; L. C. Jaffe, Picasso, tłum. K. Evert-Vaedtke. Warszawa 1969, 9-48. Cf. F. Bürtz, Faire voir ... p. 21; F. Bürtz, L'art achevé, c'est l'Art Saint!, Mess'AJE 1993, 31, p.13.

Od Maneta do Pollocka... 224-230; W. Beckett, Historia... 336-339.

F. Bürtz, Faire voir ... Ibidem. 
Theology of beauty nests. Asked by sisters: Where are the saints? The artist said that if it was a model of the saint, she would be there. Henri Matisse expressed in this way both the respect for values that he did not recognize and at the same time his doubts in their existence. In this case, the model became an abstraction for him.

Marc Chagall, ${ }^{25}$ an orthodox Jew born in Belarus, started his career as a painter. When he appeared in Paris in 1910, he began painting his fantastic visions using painting techniques borrowed from expressionists and Cubists. In art, he used color and deformation values. In order to express joy, he deprived himself of the pain of painting the characters by lifting them in the air $^{26}$. Under the influence of the atmosphere of war, he also made works on social and religious subjects. He illustrated the Bible and worked on sacred objects in France. Among other things - for the synagogue in Jerusalem - he assembled a team of twelve stained glass representing the twelve tribes of Israel. In Michel Quenot's opinion, Chagall sought the reality of invisible language borrowed from poetry. For this reason, his painting, which did not take into account theological language, found it difficult to find acceptance in sacred space ${ }^{27}$.

The above-mentioned artists created the environment in which the painter met modernity in art and penetrated into its assumptions. From the Parisian period, Françoise mentions that in her studio she wrote an inscription, ,What does it do? This question clearly suggested that the works created there were indicative of temporality. Their maturation was impossible because they were dictated by internal impulses, also dreaming, passing carelessly from one idea to another. The expression of modernist art was the transfer of elusive emotions to the ground, often by accident. This art created a break in communication between the artist and the people. It could be compared to attempting to form a coherent sentence with the accumulation of many foreign words that were incomprehensible to the reader.

Françoise Bürtz, in direct contact with the art of the avant-garde, recognized it as the true tower of Babel. This art did not give a chance for dialogue with its recipient. According to Françoise, symbols were removed to allow the Invisible to be seen through the visible. In addition to the model, the artists have set their own experiences, dreams,

25 Od Maneta do Pollocka... 65-68; W. Beckett, Historia ... p. 345; Por. Wielka kolekcja stawnych malarzy. Marc Chagall 1887-1985, Poznań 2007. Chagall 1887-1985 (lack of the autor), transl. M. Boguta, Warszawa 2006. M. Quenot, L'Icône. Fenêtre sur l'Absolu, Paris 1987, p. 91. 
doubts, fantasies or intellectual puzzles. One expression is expressed in impressionism, expressionism that diffuses the object in the plasma of reflections and colors, and another in cubism that unites living entity into geometric elements. A painter initially fascinated with avant-garde art, as she became aware of her assumptions and works created by the precursors of new directions, she began to feel insecure. First and foremost, it was not an art to which she had become accustomed since childhood. It was not about creating permanent works, but moving from one idea to another using random materials. Non-contemplative creation became a kind of production cycle, resulting in the soulless creatures of rapid invention. And although this art was fascinated by the painter, at the same time deprived of depth, she was inclined to look for something else. Young artist began to miss the harmony and creativity that would not be indifferent, and even more disgusting for the recipient. Already in 1964, she attempted to find new solutions.

\section{In search of the sacrum}

Her search for the sacred ${ }^{28}$ began where one could least expect. Staying among the "great men of this world" announced her a world-wide career. Thanks to presence in the environment, she could have great trips, visit prestigious museums and exhibitions, and continue to create art. Also, the family enjoyed and was proud of the prospect of the artist's artistic career ${ }^{29}$. Meanwhile, her impresario not only rejected the principle of creating in the old style, but also reacted violently when his colleague savored the view of the old architecture and painting. Françoise mentions that, in her delight, one of the cathedrals was ruthless, and forbidding her from seeing contemporary art with her roots,

In general, the sacrum means what belongs to the gods, and therefore is sacred: objects, devotions and holiness as such. In Judaism, holiness was understood as a value associated with the people of Israel, especially with its eminent figures, places, objects lived as sacred. The source of holiness is God, or the Other, absolutely separated from the world and all constraints and conditions. In the Bible, Israel worshiped and invoked God - Holy Israel, but was also called to holiness and to imitate God. Since God is holy, or absolutely different and separate from all creatures, then Israel should also be holy, or different and separate. In the Christianity of the Incarnation of the Son of God, the division between the sacred and the profane was questioned. Christianity perceives the world as the profane, that is, a reality that enjoys autonomy but is simultaneously attributed to God and directed towards it. Christ enables the proper consecration of creation. The liturgy of the Church, places, persons and times are not sacred, but present and invoke the saving presence of God. Cf. Sacrum, in: Encyklopedia katolicka, Ibidem, 838-842. 
he forbade her to watch ,that pig”. The painter was shocked by the extreme behavior of her masters and colleagues in various situations, which showed an aggressive attitude towards what was sanctified by tradition and brought harmony. The atmosphere of the Parisian avantgarde was closely linked to the moral revolution, which contested all social, cultural and aesthetic norms ${ }^{30}$.

Thus, the painter, in close contact with the creators of modern art, understood that this art rejects something significant, which also ceases to have significance in her personal life. She was able to appreciate what was valuable in their artistic creations, but the desire to return to the source and classical art was stronger in her. Hence, she decided to leave the environment, which she had counted on for her development, which was tantamount to rejection of her promising career. Nonetheless, it was precisely the environment in a radical way that separated itself from the cultural and artistic past, helped Françoise to rediscover the faith of childhood ${ }^{31}$. She does not hesitate to say that it was her conversion, whose process began relatively early. In her testimony she mentions that the priest accompanying her on the way back to faith on December 8, 1964, instructed her to teach the dying boy the prayer ${ }^{32}$. In this way she was to certify the maturity of her decision.

Immediately after her conversion in early 1965 she went to Châteauneuf-de-Galaure with her colleague, where she met the great modern mystic Marthe Robin. This woman's life was a unique testimony of being in a paralyzed body that was maintained for fifty years by the Eucharist. Marthe Robin, who had been ill and contracted to bed since her youth, was marked with stigmata and received her sufferings in the spirit of faith and union with God. She remained constantly in the same place being interested in the life of the Church and for the Church she offered her sufferings. No wonder that so many church dignitaries, the creators of the renewal work in the Church, came to her to seek advice, support, light and prayer ${ }^{33}$. Françoise, finding her own way of faith and expressing it through art, repeatedly was returning to Marthe to seek her inspiration. From meeting with the mystic she had two valuable tips. Because it was Marthe Robin, commenting with Jean Guitton on Paul VI's comment on Christian art, she drew

J-M. Merlin, Françoise Bürtz: l’art ... Ibidem.

31 R. Dumont, La foi par les symboles, "France Catholique" 1997, 2601, p. 19. 
attention to the need to seek the union of art with theology ${ }^{34}$. Another time, the mystic in conversation with the painter expressed the belief that art is a privileged place of the Holy Spirit. The problem, however, was that the artists did not allow him to express himself in art. The above reflections of Marthe Robin allowed Françoise to understand that in painting to communicate with and serve man, it is important to ask about the model of this art. Moreover, in religious or sacred art, fidelity to theology, which indicates the directions, content and boundaries of such art, are of importance ${ }^{35}$.

Françoise seeking harmony even before the meeting with Marthe did not go in search of what is its source in art. Platon's response to her was that of Beauty ${ }^{36}$, which, combined with Truth and Goodness, was the exclusive model of the Absolute. Ever since she realized this, she began to radically search for anything that could center her art around the Absolute who called her invisible, the Infinite, and saw in him the source of all creativity. However, after her conversion she went further, trying to read the content of the Absolute in theological terms. It was not enough to declare the existence of the superior, but began to seek the possibility of establishing a personal contact with her. In this she had to express her faith, which she found again.

Tired of current attempts to practice modern art, she decided to go to the Holy Land. During her three-year stay she sought the justification for her faith. It was filled with a thorough study of the Scriptures and Tradition written by the Fathers of the Church. Reaching into the basic sources of Christian faith, she sought in them, among other things, topics and content for the creation of a different kind of art. But more important than the pragmatic intentions was to discover new theoretical assumptions for creativity. Not without significance for these inquiries was her stay in the Holy Land. When she went to Israel and knelt in Bethlehem, she understood that the Invisible whom she had discovered in the philosophical way, in the act of the Incarnation he accepted a human face and that this face should be pictured ${ }^{37}$. Encountering the mystery of the Incarnation, Françoise found the meaning of her painting mission. First of all, this personal revelation turned the painter away from abstraction ${ }^{38}$. In her mind there was

34 J-M. Merlin, ibidem.

F. Bürtz, L'icône de la beauté et de la Revelation, Mess'AJE 1982, 9, p. 4.

See: W. Tatarkiewicz, Estetyka starożytna. Wrocław - Kraków 1960, 133-152. J-M. Merlin, ibidem. modern. Rare, originale, belle, Mess'AJE 1992 0, 29, p. 5. 
the thought that if God joined man in the Incarnation, it is impossible to utter the soul without the body. God created her in his image and likeness. This conviction allowed her to establish certain principles of new creation. She concluded that the Invisible can be expressed in art with the body, face, hands and eyes. In Bethlehem she understood that the artist, in order to give a positive response to the work of the Incarnation, should recognize the Holy Spirit as a priority model in art. By submitting his action he is only able to express his interior and his genius ${ }^{39}$. In this way, she began to paint the first images of the new generation that were in the Holy Land.

The stay in the Holy Land has also resulted in another painter's important life, which has shaped her work. There, she met the priest of the Diocese of Cambrai (France), Jacques Bernard, who studied the Talmud at the Hebrew University in Jerusalem. These studies have allowed him to see that the story of Israel's faith is centered around two fundamental experiences, which he identified with the thresholds of faith and called them successively: Exodus and Exile. In this context, he clearly saw the next two, but already in the New Testament, namely Jesus and the Church. The whole of his reflections lay in the pedagogy of faith, which he gladly shared with the artists in Jerusalem. And they expressed the will to convert the biblical ideas of the theologian into the language of art. Thus, since 1970, close cooperation between the exegetes and the painter has started, which resulted in numerous and valuable paintings of the didactic type ${ }^{40}$. As a result of Marth Robin's suggestion, they expressed the unity of art and theology. Thus began the creation of a new civilization of the religious image, which, as in the Middle Ages, was to fulfill the mission of transmitting the truths of God, the mission of preaching ${ }^{41}$. Marthe Robin led Françoise to the milieu, people, places of formation that supported her mission ${ }^{42}$. She respected her commitment to biblical adult catechesis among the coauthors of Mess'AJE ${ }^{43}$.

One of the links in shaping the artistic personality of Françoise was her trip to Russia and it was after her stay in the Holy Land. There she tried to diagnose what was a distinguishing feature of iconographic

\footnotetext{
$39 \quad$ F. Bürtz, Faire voir ... p. 22.

40 R. Dumont, Le colloque de Chavot 1998, Mess'AJE 1998, 41, p. 4.

41 J. Deledicque, Une histoire de rencontres, Mess'AJE Numéro Hors-Série 1996, p. 3 .

$42 \quad$ F. Bürtz: L'art moderne et la foi... p. 6.

43 R. Dumont, Lafoi parles symboles ... Ibidem. Cf. E. Młyńska, Bibliaw katechezie dorostych w ujęciu Jacquesa Bernarda, "Studia Katechetyczne".
} 
art, also called sacral $\operatorname{art}^{44}$. In association with the art of the East, she became convinced that it was the culmination of religious art. Her place in the hierarchy of religious works was compared to the place of the Bible in relation to literature and poetry. The icon, as she realized, is the expression of the infinity of the Holy Spirit. Written in humility forms a God-inhabited form ${ }^{45}$. Françoise, meeting with the icon, found confirmation of the truth discovered earlier in Bethlehem that the idea of these images was based on the theology of the Incarnation ${ }^{46}$. It is because God has come in the human body, man can discover the Invisible in the face of Christ ${ }^{47}$. In addition, the distinguishing feature of the Eastern Icon is that its beauty is above all a beauty of its own nature and originates in a model with a capital letter. As the icon experts say, its beauty is not related to the artistry of the image, but reveals itself in the harmony that comes from the whole. Icons do not represent beauty in itself, but a spiritual reality that is true in itself. Thanks to this, the icon carries the inner light of the one who contemplates it and thus receives $\mathrm{God}^{48}$.

The basic idea of iconographic art is painting according to strictly defined canons. These are theologies and traditions that preserve the unity and legibility of art. Consequently, both the symbolism and the subject matter and content do not come from the artist. An important fact is that the icon is not the fruit of intellectual cognition, and the spontaneous representation of the mystery written in the hand of a praying monk ${ }^{49}$. Among the rules governing the writing of icons, it is worth mentioning at least some:

1. Icons are written in ink, tempera on a properly prepared board. The use of organic materials eliminates all chemical agents.

2. Icons represent unreal characters. The beauty of their face is determined by the beauty of the interior rather than the pure aesthetics.

3. The icons are scaled in proportion. The size of the people presented depends on the role they play in the topic.

4. Faces of the Incarnation take on significant importance.

F. Bürtz, Evangile de Noël ... p. 9.

F. Bürtz: L'art moderne et la foi ... p. 7.

Cf. L. Uspienski, Teologia ikony, Poznań 1993, 123-130. K. Klauza, Teologiczna hermeneutyka ikony, Lublin 2002, 25-43.

M. Quenot, L'Icône... p. 17

Ibid. p. 17. 53. Cf. T. Špidlik, M.I. Rupnik, Mowa obrazów, Warszawa 2001, 8-20; H. J. M. Nouwen, Ujrzeć piękno Pana modląc się ikonami, Warszawa 1998, 10-12. M. Quenot, L'Icône ... p. 91. 
Theology of beauty

5. Icon ignores the principle of unity of place and time.

6. In the structure of some icons can be separated by individual staff.

7. Byzantine art abandons three-dimensional space.

8. The icon is made of divine light, so there is no shadow on it.

9. Colors have their symbolic meaning. The most common colors are: white, blue, green, red, yellow, gold, brown.

10. The iconographer is a man of prayer ${ }^{50}$.

Françoise was able to convince herself that the many canons of her master Grunewald's paintings as well as those of contemporary art corresponded with the sanctified principles of Eastern art.

After traveling, Françoise was involved in the Diocese of Cambrai in the north of France and also under the suggestion of Marthe Robin. Cambrai agreed to be her spiritual director and encouraged her to study theology, which, following the Second Vatican Council, changed her vision of God, the world, and mankind back to the source. Through her studies in Freiburg, in 1970-1973, the painter met prominent theologians such as Hans Urs von Balthazar, Jacques Gillet and Jacques Loew, who supported her in her work in combining art with theology ${ }^{51}$. During study, based on the theological analysis of the source texts and contemplation was the first theological synthesis of the painter, which was also her diploma work. In this work where the textual basis of the First Letter to the Corinthians has been fulfilled, chapter 15 has been fulfilled with the desire to impart theological knowledge with the help of a brush.

After a few years of discernment of her life and artistic mission, Françoise began to promote her own style of religious painting with the aspirations of sacred art. Eventually she settled in Lille, where she actively participated in the creation of great theological synthesizers, graphics and stained glass.

\section{Creating her own style}

The path that the painter passed through the first admirers of art in childhood, through the ambition of studying contemporary trends in the field, and then her disappointment with the temporality of art, has helped her to make a perfect return. She decided to break with the world of thought and pragmatic chaos and began to search in the art of harmony. By reaching philosophical sources for beauty, the Absolute first discovered, and spending time in Bethlehem to study

50 Cf. ibidem, 106-154.

51 J. Deledicque, Une histoire ... Ibidem; R. Dumont, La foi ... Ibidem. 
the sources of Christianity discovered the Mystery of the Incarnation paving the way for establishing personal contact with the Invisible. This ideological basis allowed her to shape her own style of religious painting. It was based on the criteria of religious art defined by the Second Vatican Council, which recognized art as a religious subject (see CSL 122). Unlike her, it regarded sacred art as the one to perform in the liturgical rites ${ }^{52}$. Françoise, after her conversion, had the desire to have her religious painting help the modern man to find his own relationship with God, and to enter the sacred space.

By creating a type of religious art, she did not neglect the achievements of modernist $\operatorname{art}^{53}$. She was of the opinion that breaking up with boring academics was necessary in order to properly express the mystery of the Model written in capital letters. And although the icon was at the top of the hierarchy of religious images, she noticed that icons in Eastern Churches set by the Church had long since ceased to be written. Today it is just copying. But recognizing the Holy Spirit as a fulfilling function of the Model in art understood that man can not limit his actions today. With the conviction that the Holy Spirit does not copy, but brings out old and new things, the need for a new iconography has arisen ${ }^{54}$. Her painting style was created in the tension that took place in her as a result of confrontation of contemporary art of the West with the sacred art of the East. The fact of the matter was that this confrontation was made in the sphere of theoretical assumptions and practical solutions.

First of all, through the period of artistic formation, she saw clearly that what determines the nature of art in general, and religious art in particular, is reduced to the problem of model. She was aware that the art that had been rejected by the present day attached importance to copying the pattern. This was outside of the artist and was the subject to reconstruction taking into account existing academic rules. In both secular and religious art, the painter usually aimed to faithfully reproduce the natural beauty of a person, an item or an object, which he copied in his own way. He took care of maintaining the proportions, setting the model in a spatial perspective, a good composition of the image, sharpening the characters with the use of shades, appropriate coloring. In modernist art, the artist did not care about copying the model and its beauty. The model has since ceased to be an object

52 Cf. K. Cichoń, (Sacrum). III. W sztuce, in: Encyklopedia katolicka, vol. 17, Lublin 2012, p. 838. 
outside and its place was taken by the artist himself and his imagination, fed with emotions, sensations or intellectual explorations. The artist's value system as well as its internal states cast very strongly on the character of the art being created. The aforementioned avantgardes were a prominent example. It is no wonder that Françoise, who grew up in the school of master Grünewald, wanted to return to the past, and to rediscover the Creator who was the creator and source of creative power, and which allowed the artist to be instrumental in showing inner beauty.

Secondly, the artist noted that both modern art and iconographic art had the means by which they could express the inner harmony of the presented realities and persons and the relationships between them. So she decided to use the achievements of modern Western art and hieratic art of the East in her work. One of these was the presentation of unreal characters, ignoring their natural beauty. By deforming the character, ignoring proportions or gestures, she tried to emphasize the depth of the individual relationship that connects man with God. In addition, the artist drawing on the experience of iconographers as well as Mattise's personally encountered color gave great importance to the symbolism of colors. However, she did not seek beauty in their mathematical game, but in the mystical presence that nourishes, teaches and enlightens. Just as the iconographers in the art they created, she ignored the prospect and the principle of unity of place and time.

In her work, as can be seen in Eastern iconography, great effort is made to best express the Invisible through the face, eyes and hands. Therefore, the faces that were painted were very different in shape, color, lines used. Sometimes, under the influence of the inspiration of Picasso, she used a face-to-face treatment of a double or triple face. Similarly, great importance was attached to expressing spiritual states through the eyes. It depended on the fact that by applying techniques to paint the eyes expressing presence. As she recalled before her conversion, she painted her eyes with colorful live and poetic stains. On the other hand, after the conversion, the eye study devoted much attention to painting them so that, in conjunction with their face, they expressed the depths of inner life. It was up to the eyes that the contemplative images became „the mirror of the life of grace.” While she was painting the pupils of the eye, she put on some colored patches, so she tried to show them like the pupils of the soul. In turn, hands and gestures conveyed the message to the recipients of the hearts of the characters presented. Similarly, as in the eastern icon with the face, eyes, hands expressed the state of grace, which transforms the man 
with the sense of vision of the whole, it attached importance to painting with great precision of the face, even if they were a few centimeters ${ }^{55}$.

The preferred means of expression in F. Bürt's art are symbols, some taken from the Bible, others from the writings of the Fathers of the Church. Nevertheless, the artist decided on the type of figurative painting, not copying so far recognized patterns in biblical iconography. In this situation, the use of symbols helped the recipients of her work in identifying the biblical figures she placed on her paintings. This treatment proved to be all the more correct in the case of the creation of great theological syntheses based on numerous biblical events, and consequently numerous figures on the images. In turn, the artist's passion for use in the art of symbolism can be easily seen in the forms of paintings. For example, The Passion according to Saint John painted on the plan of the Byzantine cross, The Creation set in the cosmos was expressed in the form of circle, The Gospel of childhood according to Saint Luke expressed in the form of a triptych, and The creed of the early Christian church placed in the shape of the window of the ancient basilica.

In modern art, the artist most irritated the artist, that is, an art that detached man from reality ${ }^{56}$. She realized that the more the form of the image was empty, the more unconstrained it was in the combinations. This image usually shows the devastation of the soul and awakens in the recipient rather disgust and anxiety. This extraordinary experience of the mystery of the Incarnation in Bethlehem confirmed her belief that one cannot represent a soul without a body. The invisible, who is in the human being, cannot express himself only by the wisdom that has lost his body. She was convinced that it was necessary to create paintings in order to preach the mystery and to be truly similar to the Model for which the Holy Spirit was acknowledged. For this reason, she decided on figurative painting.

The most valuable works of the artist are the great theological syntheses, as a result of close cooperation between the painter and the theologians ${ }^{57}$. This faithfulness to theology makes her paintings truly a kind of book that can be read and from which one can learn the faith, more - feel invited to dialogue with God. Francis's great theological synthesis is called the preaching icon. They are the place to visualize theology, so that the recipients can learn and contemplate the whole subject of the faith. Françoise appreciated the cooperation with the

\footnotetext{
55 J-M. Merlin, ibidem.

$56 \quad$ F. Bürtz: L'art moderne ... Ibidem.

$57 \quad$ R. Dumont, La foi ... Ibidem.
} 
Theology of beauty

exegete. By transforming into the language of the image difficult scientific content, she felt that she participated in the work of proclaiming the Gospel in her own way. She rarely painted small forms or single figures. On the other hand, great themes, such as Christmas, appeared in the context of the entire history of salvation. Similarly while painting The Passion according to Saint John she presented all scenes of this description, framing the intended image. In her rich output also she has stained glass made for large sacral space and numerous graphics.

The painter treats her paintings as icons that lead through contemplation to the encounter with God, and therefore she places great importance on the prayer, study and meditation of the Word of God ${ }^{58}$. She leads a hermit life, prays and contemplate the Holy Scriptures, the Fathers of the Church, and theology. She considers that the icon can be treated as a means of proclaiming God's Word primarily because it is born of the artist's personal relationship with God. In her opinion, a painter who opens up to the action of the Holy Spirit and engages his genius is capable of creating works of a religious and sacred character. John Paul II in the Letter to the Artists says: ,... the divine breath of the Creator Spirit when he meets the genius of man awakens his creative capacity. (...) He connects with it through a kind of inner revelation which contains in itself an indication of good and beauty, and awakens in man the powers of mind and heart, thereby enabling him to take up an idea and to give it form in the work of art"59. Although few works of the painter directly serve the liturgy, yet all theological images that make up suitable for meditation and can lead to the experience of the sacred.

\section{Painting of theological icons}

Among the greatest works of Françoise Bürtz are the following: 1 Corinthians 15, Blessings, The Gospel of childhood according to Saint Luke, The Passion according to Saint John, The Creation, AscensionPentecost and The Creed ${ }^{60}$. These images always contain specific theological treatises, or biblical events in the context of the history of faith. The painter made them on large sizes of wood, using the principle of oil paints. Usually, the form of the image depends on its content. While creating the synthesis, she placed a series of scenes related to the subject next to each other, so her images in the first contact overwhelm

\footnotetext{
$58 \quad$ Cf. Lettre de Françoise Bürtz, Mess'AJE, 27, 1991, p. 5. 
the number of characters and symbolic props. However, thanks to the process of framing scenes and choosing the appropriate formats, we can quickly find the content presented. A characteristic feature of images called didactic is that some biblical characters appear in several different scenes in the same image. The genius of the painter makes them all coherent compositions. In this sense they can help us to comment on selected works.

\section{Cor 15}

This is the first theological synthesis of the artist based on the content of the fifteenth chapter of the First Letter to the Corinthians. It was established in Jerusalem in the seventies of the twentieth century. It was painted on wood with oil paint. This painting is the only painting that focuses attention on the indications of the letter of St. Paul. The painter, when confronted with an unexplainable subject, encountered the difficulty of painting God the Father, who no one had seen. She decided to give Him the form of a human face, but without sight, because $\mathrm{He}$ was revealed only by His Son. This St. Paul's text about the Resurrection of all things has come to Isaiah's vision, in which there are plants, seeds and animals. Christ as new Adam culminates in the story of Revelation. Crucification on the cross is present in this world and in the world of glory. The pierced heart of Jesus receives the Holy Spirit, who brings it alive. From the pierced heart is born the Church shown as a place of baptism (feet in water), place of healing (face of healed), place of prayer (faces focused on the church and the chalice), and in particular the proclamation of the Gospel (face concentrated on the book). The Church, born from the pierced side of Christ, destroys the power of evil rooted in Adam's sin. The apostles present at the foot of the cross together with Mary present the mystery of the Church before the throne of the Lamb. Mary is already the Bride of the Holy Spirit, who does not know death. One of the Apostles refers to the prophets centered on the cult of the Law, pictured by the tablets and to a new cult centered on the Chalice of Christ.

\section{The gospel of childhood according to the Saint Luke}

The painting is a record of the Mystery of the Incarnation of the Son of God in the context of the whole story of salvation. The image is shown in the form of a triptych. In its first wing, the genealogy of Jesus Christ was written, beginning with Adam and Eve. In the central scene, the nativity scene was featured, but also important events in the 
life and work of Jesus. Scene three expresses the apocalyptic vision of the Kingdom of God. The whole is a figure of a woman clothed in the sun and moon under her feet. This is an image of the Mother Church embracing humanity. In the picture you can see many borrowings from colours in the outline of the face.

\section{The Passion according to Saint John}

The painting was painted on a cross. It illustrates the whole Passion according to the record of John. It begins with the scene of Jesus with the disciples in the Cenacle, which scene is closely related to the Passion. The image was divided into five columns. The first depicts the capture of Jesus in the Garden, the second scene with Annas, the third trial with Pilate, the fourth with Golgotha, and the fifth with the grave. The whole consists of twenty one frames. The central column is made up of seven frames and represents the entire trial of Jesus at Pilate. In the description of the Passion it is a central scene. John the Evangelist does not emphasize the wounds of Jesus, but he wears Christ in purple, showing that he is truly the king and has power over Pilate. The painter emphasized the importance of Jesus by shifting the proportions between the main characters of this scene. The first column highlights the contrast between light and darkness, paying attention to one of the leading themes of the Gospel of St. John. The scene in Annas is dominated by the figure of Peter, who was warmed up by the fire and did not have the courage to confess to his Master. In the fourth scene at Golgotha, we see a cross shaped like a mast of a boat, which is a symbol of the Church. In the last scene, we return to the Garden, symbolized by green trees, to show the life-giving dimension of the death.

\section{The Creed}

This work was done for pastoral purposes in order to serve the adult catechumens in their preparation to be baptized. Presenting the truths of the Church in the image as a reality, which was not visible, it was a great challenge for the painter. Another thing is painting the biblical events, and something different is painting the abstract content. In this work, it was above all to express the mystery of the faith. The artist began painting Mary, who told God „yes” she became a guide to the faith of the whole Church. Then, she painted great Christ in the center in the color of purple resembling His Passion, and the great hand that separates the Kingdom of God from hell. The Holy Trinity expressed 
by the symbol of the hand of God the Creator, the face of Jesus and the flame signifying the Holy Spirit. All other mysteries connected with the life of Christ and the Church have been taken in the symbolic scenes around Christ and Mary. The second hand of Christ in the image rests on the head of the bishop, in order to say how great the relationship of Christ with the successors of the apostles, the foundation of the Church. In the lower left frame there are all the saving mysteries associated with the order of the Redemption, and at the bottom right there are the sacraments as the saving fruit of the Passion, the Death and the Resurrection of Jesus.

\section{Conclusion}

Françoise Bürtz's painting art was created at the confluence of the modern Western culture and sanctified by the tradition the Eastern culture, and is an excellent example of the opening of the artist to the values present in each of them. As a result of the painter's attitude became her work, not ignoring the achievements of contemporary painting, and at the same time seriously regarded theological premises. In this way she created a new civilization of religious image, widely used in biblical adult catechesis on several continents. The theme of our thinking on the subject has been ordered by the topic of the model in art. It emerged during the analysis of the art in this article. Françoise helped us to notice it, who reflects on the philosophy of art while painting.

\section{MALARSTWO FRANÇOISE BÜRTZ NA STYKU NOWOCZESNOŚCI I SACRUM}

Współczesna francuska malarka Françoise Bürtz studiując od roku 1962 sztuki piękne w Paryżu doświadczyła kryzysu malarstwa XX wieku W spotkaniu z przedstawicielami awangardy francuskiej tej miary co: Henri Matisse, Marc Chagall, Pablo Picasso a jednocześnie filozofami torującymi drogę sztuce nowoczesnej w osobach Jean Paul Sartre'a, czy André Malraux mogła wystarczająco dobrze poznać jej przejawy i założenia. Sztuka z jaką się zetknęła nosiła znamiona tymczasowości, a tworzenie pozbawione kontemplacji stawało się cyklem produkcyjnym, którego efektem były bezduszne twory szybkiej inwencji. Françoise Bürtz zniechęcona wytworami pozbawionej głębi sztuki zaczęła poszukiwać czegoś innego. Porzuciła środowisko, które mogło jej zapewnić artystyczną karierę. Po doświadczeniu osobistego powrotu na drogę 
Theology of beauty

wiary podjęła inicjatywę kształtowania takiej sztuki, która prowadziłaby jej odbiorców do osobowego kontaktu z Bogiem. W wypracowaniu oryginalnych założeń nowego stylu tworzenia pomógł jej kontakt ze stygmatyczką Marthe Robin, z egzegetą twórcą Mess'AJE Jacquesem Bernardem, a także pobyt w Ziemi Świętej, studia teologiczne we Fryburgu Szwajcarskim orasz podróż do Rosji. W oparciu o te doświadczenia jak również kontemplację tekstów biblijnych i Ojców Kościoła stworzyła nowa cywilizację obrazu religijnego, w którym połączyła osiągnięcia sztuki współczesnej z próbą wyrażenia tego, co niewidzialne. Jej liczne dzieła są rodzajem wielkich syntez teologicznych stanowiących ważną pomoc w kształceniu biblijnym dorosłych na kilku kontynentach. Sztuka ta łącząc w sobie nowoczesne środki wyrazu z głębią tajemnicy wiary skutecznie prowadzi współczesnego człowieka na spotkanie z sacrum.

Słowa kluczowe: awangarda francuska, ikonografia wschodnia, syntezy teologiczne, model w sztuce, sacrum.

\section{Bibliography:}

1. Beckett W., Historia malarstwa. Wędrówki po historii sztuki Zachodu, transl. H. Andrzejewska, I. Zych, Warszawa 1996.

2. Bürtz F., Evangile de Noël, Lille 1991.

3. Bürtz F., Faire voir l'invisible, Mess'AJE Numéro Hors-Série 1996.

4. Bürtz F., L'art achevé, c'est l'Art Saint!, Mess'AJE 1993, 31.

5. Bürtz F., Licône de la beauté et de la Revelation, Mess'AJE 1982, 9.

6. Deledicque J., Une histoire de rencontres, Mess'AJE Numéro Hors-Série 1996.

7. Dumont R., La foi par les symboles, "France Catholique" 1997, 2601.

8. Dumont R., Le colloque de Chavot 1998, Mess'AJE 1998, 41.

9. Esquier H., Françoise Bürtz. Une peinture qui dit l'espérance, o sein de l'art modern. Rare, originale, belle, Mess'AJE 1992 0, 29.

10. F. Bürtz nous entretient de la peinture, Mess'AJE 1982,10.

11. F. Bürtz: L'art moderne et la foi, Mess'AJE 2001, 46.

12. Gombrich E.H., O sztuce, Wyd. II. Poznań 2009.

13. Jaffe L. C., Picasso, tłum. K. Evert-Vaedtke. Warszawa 1969.

14. John Paul II, The Letter to the Artists, Vatican 1999.

15. Klauza K., Teologiczna hermeneutyka ikony, Lublin 2002.

16. Lettre de Françoise Bürtz, Mess'AJE 1991, 27.

17. Levey M., Od Giotta do Cézanne'a. Zarys historii malarstwa, transl. M. Bańkowska. S. Bańkowski, Warszawa 1972.

18. Meaney E., Representation and synthesis in Françoise Bürtz's Religious Art, Spring 1997, p. 12. Arch. Mess'AJE, Lille.

19. Merlin J-M., Françoise Bürtz: l'art comme une vocation, in: Troisième seuil. Jésus. Guide d'animation, ed. III, Lille 2013 annexe 1.2.

20. Mittelstädt K., W kręgu sztuki. Matthias Grünewald, Warszawa 1988.

21. Młyńska E., Biblia $w$ katechezie dorostych $w$ ujęciu Jacquesa Bernarda, "Studia Katechetyczne". 
22. Nouwen H. J. M., Ujrzeć piękno Pana modląc się ikonami, Warszawa 1998.

23. Od Maneta do Pollocka. Stownik malarstwa nowoczesnego. Praca zbiorowa, transl. H. Devechy, Warszawa 1995.

24. Poprzęcka M., Academizm, Warszawa 1989.

25. Quenot M., L'Icône. Fenêtre sur l'Absolu, Paris 1987.

26. Słownik terminów plastycznych, K. Zwolińska, Z. Malicki, 5th ed. 1974.

27. Špidlik T., Rupnik M.I., Mowa obrazów, Warszawa 200.

28. Tatarkiewicz W., Estetyka starożytna. Wrocław - Kraków 1960.

29. Témoignage de Françoise Bürtz, Mess'AJE 1992, 30.

30. Uspienski L., Teologia ikony, Poznań 1993.

31. Wielka kolekcja stawnych malarzy. Marc Chagall 1887-1985, Poznań 2007. 